\title{
Ruslands redningsmann - en politisk biografi om Vladimir Putin
}

\author{
Bjørn Nistad \\ Oslo: Vidarforlaget 2016 \\ 332 sider. ISBN: 9788279903093
}

Anmeldt af Per Dalgård [cand.phil., ph.d., freelance korrespondent, forfatter og rejseleder i Rusland, pdribe@gmail.com]

Jeg er tit blevet »anklaget« for at være Putin-apologet, ja, jeg har sågar i Danmark fået afvist et bogmanuskript fra et forlag med den begrundelse, at jeg var for positiv overfor den russiske præsident og for Rusland. Indrømmet, jeg er mere positiv indstillet overfor udviklingen i Rusland under Putin end de fleste kommentatorer, og jeg mener, at den danske og vestlige dækning af situationen i Rusland grundlæggende er forkert, fordrejet, negativ og fjendtlig.

De vestlige medier og mange forskere har travlt med at beskylde Putins Rusland for aggressivitet, koldkrigstænkning, korruption og undertrykkelse af menneskerettigheder og demokrati. Og de har selvfølgelig noget at have det i, men i grunden er de selv mere koldkrigstænkende end russerne i deres totalt ensidige kritik af Putin og Kremls styre. Vesten har bestemt også en stor del af skylden. Og der er også en anden side af det moderne Rusland, som vi i Vesten sjældent hører om, nemlig de talrige positive forandringer, der er sket siden Sovjetunionens sammenbrud i 1991.

Jeg trænger i den grad til et mere nuanceret billede af Rusland i dag og for den sags skyld også af Vladimir Putins regeringstid og dens resultater. Men norske Bjørn Nistad går efter min mening helt over på den anden side af spektret og beskriver fuldstændig ukritisk Putin og hans politik i sin nye bog Russlands Redningsmann, selvom det faktisk er befriende at læse en bog, som forsøger at se ud over stereotyperne og den vanlige vestlige synsvinkel, som man i Vesten betragter som »ÅH så vigtig« og » $\mathrm{A} H$ så rigtig«.

Nistad sætter fingeren på det rette ømme punkt, nemlig på det faktum, at Putin ved sin magtovertagelse i 2000 var åben, pragmatisk og indstillet på et tæt samarbejde med Vesten. Og Nistad har ret $i$, at det nuværende dårlige forhold mellem Rusland og Vesteuropa, NATO og USA kunne have været undgået, hvis Vesten havde holdt sine løfter, havde hjulpet det vaklende Rusland i 1990'erne, og, ikke mindst, havde holdt løftet om ikke at bringe NATO et skridt i retning af Rusland. 
Hvad er det vi har set? USA og NATO, som omringer Rusland, vestlige (læs USA og NATO) forsøg på at vinde indpas i Centralasien, Kaukasus, Ukraine og hele Østeuropa. Og så de fjollede opstillinger af missilskjold i Østeuropa med den begrundelse, at de er vendt imod »slyngelstater « som for eksempel Iran. Enhver kan se, at der er tale om en opbygning af en trussel imod det Rusland, som under Gorbatjov, Jeltsin og den tidlige Putin rakte en venskabelig hånd ud imod Vesten.

Resultatet af Vestens koldkrigeriske politik, eller i bedste fald ignorance, mod Rusland blev det, som vi ser i dag: vestligt støttede og finansierede orange revolutioner, der kupper moskvatro styrer, Moskvas modreaktioner med magt, krig i Sydossetien, overtagelse af Krim og krigen i Østukraine. Mens vi er venner med morderiske regimer som Saudi-Arabien, Kuwait, Kina og mange andre, så bekæmper vi verdens største land, som siden 1991 har forsøgt at bevæge sig i retning af »civilisation", som har droppet dødsstraf (i modsætning til USA, Kina, Saudi-Arabien og mange andre), gennemført reel religionsfrihed, afskaffet i hvert fald litterær censur, har åbnet grænserne for sine borgere og forbedret levestandarden radikalt for borgerne, men som af velbegrundet skræk for vestlig indblanding har følt sig tvunget til at begrænse borgerrettighederne. Som Nistad med god begrundelse skriver, så har Putin fået skabt ro i Tjetjenien, om end med brutal vold, fået styr på anarkiet fra Jeltsin-tidens voldsomme (men nødvendige) reformer og fået tilkæmpet Rusland en magtfuld plads i verdenssamfundet - hvilket er årsagen til hans fortsatte popularitet.

»Korruption!« vil mange sige. Ja, der er tale om en omfattende korruption, og det seneste års afsløringer fra Panama tyder på, at i hvert fald Putins inderkreds er involveret. Men det er de jo også på Island, i England og over hele verden. Ikke desto mindre har Putin genrejst Rusland, som Nistad skriver, som en anden De Gaulle og Churchill.

Læs denne velskrevne og veldokumenterede bog, som et modigt partsindlæg i øst-vest-dialogen, og sammenlign den med de daglige artikler og tv-udsendelser, så finder du en form for sandhed et sted midt imellem de to synspunkter. 